\title{
Covid-19 Salgını Sürecinde Taşımalı Öğrencilerin Uzaktan Eğitim ile Verilen Fen Bilimleri Dersine Yönelik Görüşleri
}

\author{
DOI: $10.26466 /$ opus. 915874
}

$*$

\section{Sinem Karataș Öztürk *}

${ }^{*}$ Milli Eğitim Bkanlığ

E-Posta: sinemkaratas1207@gmail.com

ORCID: $0000-0001-8198-7350$

Öz

2019 yılının aralık ayında Çin' in Wuhan kentinde ortaya çıkan virüs Dünya Sağlık Örgütü tarafından Covid- 19 olarak adlandırılmıştır. Bu nedenle ülkeler özellikle eğitim sektöründe bir dizi önlem almaya çalışmıştır. Ülkemizde ise 13 Mart 2020 tarihinde uzaktan eğitim faaliyetleri başlatılmıştır. Araştırma Covid- 19 salgını sürecinde taşımalı öğrencilerin uzaktan eğitimle verilen fen dersine yönelik görüşlerini belirlemek amacıyla yapılmıştır. Bu amaç doğrultusunda nitel araştırma desenlerinden durum çalışması kullanılmıştır. Araştırmanın çalışma grubunu Muğla ili Milas ilçesine bağlı bir köy okulunda 2020-2021 eğitim öğretim yılında ortaokul 5., 6., 7. ve 8. sinıf düzeylerinde öğrenim gören 20 öğrenci oluşturmaktadır. Çalışma grubu ölçüt örnekleme yöntemi ile belirlenmiştir. Veri toplama aracı olarak 7 sorudan oluşan yarı- yapılandırılmış görüşme formu kullanılmıştır. Veriler içerik analizi yöntemi kullanılarak analiz edilmiştir. Çalışmanın sonunda taşımalı sisteme dâhil olan ve Z kuşă̆ında yer alan ortaokul öğrencilerinin, uzaktan eğitimle verilen fen bilimleri dersine yönelik olumlu düşüncelere sahip oldukları tespit edilmiş̧ir. Öte yandan fen dersleri için daha fazla animasyon, video, belgesel, kaynak kullanılması, yönünde görüş bildirmişlerdir.

Anahtar Kelimeler: Fen eğitimi, covid- 19, fen dersi, taşımalı eğitim, uzaktan eğitim. 


\title{
The Opininons of Bussed Education Students About Science Lessons Given With Ditance Education During Covid-19 Pandemic
}

\begin{abstract}
The virus that emerged in Wuhan, China in December 2019 was named Covid-19 by the World Health Organization. Therefore, countries have tried to take a series of measures, especially in the education sector. In our country, distance education activities were started on 13 March 2020.The research was conducted to determine the views of bussed students on distance education science lessons during the Covid-19 outbreak.For this purpose, the case study was used in the study. The study group of the research consists of 20 students studying at the 5 th, 6 th, 7 th and 8 th grade levels in a village school in the Milas district of Muğla province in the 2020-2021 academic year. The study group was determined by the criterion sampling method.A semi-structured interview form consisting of 7 questions was used as a data collection tool. The data were analyzed using content analysis method. At the end of the study, it was determined that middle school students included in the bussed system and in the generation $\mathrm{Z}$ have positive thoughts about the science lesson given by distance education. On the other hand, they expressed their views on the use of more animations, videos, documentaries, and resources for science lessons.
\end{abstract}

Keywords: Science education, covid-19, science lesson, bussed education, distance education. 


\section{Giriş}

2019 yılının Aralık ayında Çin'in Wuhan şehrinde bilinmeyen bir pnömoni tespit edilmiş ve ilk olarak 31 Aralık 2019'da Çin'deki Dünya Sağlık Örgütü (DSÖ) Ülke Ofisi'ne bildirilmiştir. Bu bildirimden sonra DSÖ, verileri analiz etmek, tavsiyelerde bulunmak, ortakları koordine etmek, ülkelerin hazırlanmasına, tedariklerini artırmasına ve uzman ağlarını yönetmesine yardımcı olmak için yoğun bir çalışma içerisine girmiştir. Salgin, 30 Ocak 2020'de Uluslararası Halk Sağlı̆̆ tarafından Acil Durum olarak ilan edilmiş ve 11 Şubat 2020'de DSÖ, yeni koronavirüs hastalığı için “COVID-19” ismini açıklamıştır. 2019-2020 yılı bahar döneminde Covid-19 salgın nedeniyle hemen hemen tüm ülkelerde eğitim kurumları kapatılmıştır (Daniel, 2020). Devam eden süreçte ise, öğretim faaliyetlerinin devam etmesi açısından uzaktan eğitim gündeme gelmiştir. Buna bağlı olarak ülkelerin tamamına yakınında eğitime uzaktan devam edilmiştir (Sarı, 2020). Bu gelişmelere paralel olarak ülkemizde de uzaktan eğitim önem kazanmış ve eğitim-öğretim sürecinin aksamaması için kayda değer planlamalar yapılmıştır (Şeren ve Kesten, 2020). Bu planlamalar arasında Milli Eğitim Bakanlığı' nın, Eğitim ve Bilişim Ağı' nın altyapısını güçlendirmesi ve Türkiye Radyo Televizyon Kurumu ile işbirliği yaparak Eğitim ve Bilişim Ağı (EBA) TV' yi kurması yerini almıştır (Özer, 2020). Böylelikle öğrenciler gerek EBA üzerinden, gerek televizyon aracil1ğıyla, gerekse diğer çevrim içi ortamları kullanarak uzaktan eğitime devam etmişlerdir.

\section{Uzaktan Eğitim}

İletişim teknolojilerinin gelişmesi, birçok uzamın tek bir platform üzerinde birleştirilebilmesini sağlamıştır. Bu durum toplumlara mesafenin olmadığ bir yakınlık sağlayarak yeni eğitim modellerinin meydana gelmesine 1şık tutmuştur. Uzaktan eğitim bu eğitim modellerinden biridir (Elitaş, 2017). 21. yüzyıla gelindiğinde ise popülaritesi ve kullanımı artan yaygın bir eğitim olarak karşımıza çıkmaktadır (Saykılı, 2018). Uzaktan eğitim, uzaktan öğrenme, çevrimiçi öğrenme ve e-öğrenme kavramları genellikle birbirlerinin yerine kullanılmalarına karşın, uzaktan eğitim en geniş ve en yaygın terim olarak literatürde yerini almıştır (Moore, Dickson Deane ve Galyen, 2011). Uzaktan 
eğitim, öğreten, öğrenen ve öğrenme kaynakları arasında yer alan sınırlı durumları ortadan kaldırma çabası içinde olan, bunu yapabilmek adına mevcut teknolojileri işe yarar bir çerçevede kullanan alandır (Bozkurt, 2017). Öğrenenin ve öğretenin aynı anda ve ayn yerde bulunma zorunluluğu olmadan, birbirinden haberdar olduğu ve teknoloji sayesinde iletişimin sağlandığı bir eğitim ortamıdır (Özarslan, Kubat ve Bay, 2007). Özetle, farklı ortamlarda bulunan öğretmen, öğrenci ve eğitim aracının teknoloji sayesinde bir araya getirildiği bir ortam olarak tanımlanabilir (Etlioğlu ve Tekin, 2020).

Son yıllarda ülkemizde teknolojik gelişmelere yapılan yatırımın arttırılması, iletişim alt yapısının güçlendirilmesi, çevrimiçi ortamların artmasını ve uzaktan eğitimin yapıldığı uygulamaların yaygınlaşmasını sağlamıştır (Kırık, 2014). Öyle ki, tüm dünyada olduğu gibi ülkemizde de Covid-19 pandemi döneminde, okul öncesinden başlayarak yükseköğretime kadar tüm öğretim kademelerinde uzaktan eğitim yapılmıştır. Bu süreçte öğrenciler ve öğreticiler çevrimiçi birçok ortamda bilgi akışın sağlamışlar, eğitime devam etmişler ve böylelikle eğitim-öğretim sürecinden uzaklaşmamışlardır.

Eğitim-öğretim süreci devletin tüm vatandaşlarına eşit olarak sunduğu bir hizmet olduğu için kesintisiz devam etmesi gereken önemli bir süreçtir. Yaşanan bu pandemi döneminde de eğitim-öğretimin aksamaması amacıyla yapılan uzaktan eğitimin olumsuz yönlerinin olmasına rağmen olumlu yönlerinin fazla olması da dikkat çekici bir durumdadır. Uzaktan eğitim özellikle öğretim süreçlerinde, öğrencilere dönüt verememe, sosyal alan oluşturamama, bireysel farklılıkları dikkate alamama, yeterince odaklanamama gibi dezavantajlı özellikler taşısa da, öğrenciler için birçok avantajlı durumlar yaratmaktadır. Bu durumlar, tekrar/pekiştirme, esnek yapı, öğrenmeyi öğrenme, bilime yönelik ilginin artması, bilimselliklerinin geliştirilmesi ve sorgulama becerilerinin arttırılması şeklinde sıralanabilir (Başaran, Doğan, Karaoğlu ve Şahin, 2020). Bu durum, eğitim kurumlarının açlamayacağı yerlerde, dağınık yerleşmenin olduğu bölgelerde veya bireylerin eğitim kurumuna gidemeyeceği zamanlarda taşımalı eğitime alternatif olarak uzaktan eğitimin daha faydalı olabileceğini gündeme getirmiştir. Çünkü taşımalı eğitim ile öğrenim gören öğrencilerin eğitim-öğretim süreçleri ile ilgili çeşitli zorluklar ve sorunlar ile karşı karşıya kaldıkları görülmektedir (Çabuk Kaya, 2006). 


\section{Taşımalı Eğitim}

Nüfusu az olan ve dağınık yerleşim yerlerinde yer alan ya da öğretime uygun olmayan eğitim kurumlarındaki öğrencilerin, yönlendirildikleri merkezlerdeki eğitim kurumlarına günü birlik taşınarak eğitim-öğretim sürecine dâhil edilmesine taşımalı eğitim denmektedir (Orhan, 2019). Eğitimde firsat eşitliğinin sağlanması, eğitim sürecinin kalitesinin arttırılması, yapılan iç göçler ve dağınık yerleşmelerin olması nedenleriyle ülkemizde 1989-1990 eğitim-öğretim yılından itibaren taşımalı eğitim uygulanmaya başlamıştır (Özgün, 2007). Nüfusu az ve dağınık olan, okulu bulunmayan yerleşim birimlerindeki öğrencilerin nitelikli eğitime kavuşturulması ve sekiz yıllık zorunlu eğitimden her öğrencinin eşit derecede yararlanmasının sağlanması amacıyla, merkez olarak seçilen okullara öğrencilerin günü birlik taşınması taşımalı okulları ortaya çıkarmıştır (Yurdabakan ve Tektaş, 2013).

Taşımalı eğitimin olumlu yönleri olduğu gibi olumsuz yönlerinin fazla olması dikkat çekmektedir. Çabuk Kaya (2006), yaptığı çalışmasında taşımalı eğitimin öğrencilerin sabahları servise binmek için çok erken kalkması, düzenli kahvaltı yapamamaları, aç karnına derse girmeleri ve derslere dikkatlerini verememeleri gibi olumsuz yönlerinin bulunduğunu belirtmiştir. Bu durumlar ise öğrencilerin fen bilimleri derslerinde başarılı olamamalarına, derse dikkatlerini verememelerine ve derse yönelik tutumlarının olumsuz yönde etkilenmelerine neden olmaktadır (Gürbey, Ezberci Çevik ve Şahin, 2020). Ayrıca fen bilimleri dersinin ulusal düzeyde yapılan sinavlarda önemli bir katsayıya sahip olması, soru sayısının fazla olması ve ayırt edici özelliğinin yüksek olması bu dersin önemini daha da arttırmıştır. Bu bağlamda taşımalı eğitim ile öğrenim gören öğrencilerin bu tür sorunları yaşamamalarına yönelik uzaktan eğitim bir çözüm olarak değerlendirilebilir. Çünkü günümüzde, Covid-19 salgını nedeniyle internet aracılığıyla çevrim içi ortamlarda eğitimine uzaktan devam eden internet teknolojileri ve dijital donanımların günlük hayatlarının bir parçası olan Z kuşağı öğrencilerinin fen dersini uzaktan ciddi sorunlar yaşamadan devam ettirebildikleri görülmektedir (Bostan Sar1oğlan, Altaş ve Şen, 2020; Pınar ve Dönel Akgül, 2020; Somyürek, 2014). Bununla ilgili olarak Bostan Sarığlan vd. (2020), fen öğretmenlerinin uzaktan eğitim sürecinde fen bilimleri dersinde yer alan deney uygulamalarında zaman tasarrufunun sağlandığını, deney yapmanın güvenli hale geldiğini, eksik malzeme ve deney hatalarıyla karşılaşmadıklarını ve bu şekilde konunun 
daha kolay pekiştirildiğini ifade ettiklerini belirtmişlerdir. Ayrıca ortaokul öğrencileri uzaktan eğitim ile verilen fen bilimleri dersinde konu tekrarları ile konuları pekiştirdiklerini, ev ortamında derslere daha iyi motive olduklarını, sınavlara daha iyi hazırlanabildiklerini, birçok dijital kaynaktan bilgiye ulaşabilme imkânı bulduklarını ifade etmişlerdir (Pınar ve Dönel Akgül, 2020). Buna bağlı olarak uzaktan eğitim ile öğrenim gören $\mathrm{Z}$ kuşağı öğrencilerin bu duruma kolay adapte oldukları ve bu durumun onlara önemli katkılar sağladığı görülmektedir.

\section{Z Kuşağı}

2000 yılı ve sonrasında doğan bireylere $\mathrm{Z}$ kuşağı denilmektedir. Bu kuşak bireyleri, bilgileri çok hızlı alabilmekte, analiz edebilmekte ve bunlara yorum getirebilmektedir (Mishra, Sarkar ve Singh, 2012, s.7). Öte yandan bu kuşak, teknolojiyi hızlı bir biçimde kavrar, işlerini kısa zamanda yapmaktan hoşlanır ve verilen birçok görevin üstesinden hızla gelebilir (Ayhün, 2013). İçinde bulunulan dönemin olanaklarına huzlı ulaşabilen ve onları etkin bir biçimde kullanabilen bir kuşaktır (Sarıbaş, Kömürcü ve Güler, 2016). Öğretim süreçlerinde sadece metin içeren bilgiler $Z$ kuşağı öğrencilerinin dikkatini çekmediğinden, bu öğrencilere bilginin resim, video, ses gibi görsel ve işitsel olarak verilmesi gerekmektedir (Savaş ve Karataş, 2019, s.230). Z kuşağı bireyleri, doğası gereği teknolojiye bağlıdır ve öğrenme süreçlerinde dijital ve teknoloji odaklı öğretimler gerçekleştirildiğinde son derece başarılı olabilmektedirler (Kapil ve Roy, 2014).

$\mathrm{Bu}$ durumda çalışmanın $\mathrm{Z}$ kuşağına denk gelen ortaokul öğrencileriyle yürütülmesi önem kazanmaktadır. Covid-19 salgın sürecinde ve önceki dönemde uzaktan eğitimle fen dersi öğretimi konusunda yapılan çalışmalara rastlamak mümkündür ( Ballıel Ünal, 2017; Bakioğlu ve Çevik 2020; Pınar ve Dönel Akgül, 2020; Tanık Önal ve Önal, 2020). Ancak taşımalı öğrencilerle fen bilimleri dersinde yapılan çalışmalara ( Gürbey vd., 2020) ve taşımalı öğrencilerle yapılan uzaktan eğitim çalışmalarına (Ozan, 2008) az rastlanmaktadır. Bu nedenle, Covid- 19 salgın sürecinde teknolojiyi hayatlarının her aşamasında rahatlıkla kullanan $Z$ kuşağı ve okula taşımalı olarak gelen öğrencilerin, özellikle soyut kavramların yer aldığı, kavram yanılgılarının fazla olduğu ve ana dersler içerisinde önemli bir yere sahip olan fen bilimleri dersini 
uzaktan eğitimle almalarına yönelik görüşlerini belirlemek alan yazına katkı sağlayacaktır.

Tüm bunların ışığında araştırmanın problem cümlesi şöyledir: Covid-19 salgını sürecinde taşımalı eğitim uygulaması ile farklı sınıf düzeylerinde öğrenim gören ve $Z$ kuşağında bulunan ortaokul öğrencilerinin uzaktan eğitimle verilen fen bilimleri dersine yönelik görüşleri nelerdir?"

\section{Yöntem}

Taşımalı eğitim uygulaması ile farklı sınıf düzeylerinde öğrenim gören ortaokul öğrencilerinin pandemi döneminde uzaktan eğitimle verilen fen bilimleri dersine ilişkin görüşlerini belirlemeyi amaçlayan bu çalışmada, nitel araştırma yöntemlerinden biri olan durum çalışması modeli kullanılmıştır. Durum çalışmasında bir ya da birkaç durum derinlemesine incelenebilmekte, bir duruma yönelik etkenler (ortam, bireyler, olaylar, süreçler vb.) bütüncül bir yaklaşımla araştırılabilmekte ve ilgili durumu nasıl etkiledikleri ve etkilendikleri üzerine odaklanılabilmektedir (Yıldırım \& Şimşek, 2011, s.77).

\section{Çalışma Grubu}

Araştırmada amaçlı örnekleme yöntemlerinden ölçüt örnekleme yöntemi kullanılmıştır. Ölçüt örnekleme, önceden belirlenmiş bir dizi ölçütü karşılayan durumların çalışılmasıdır (Yıldırım ve Şimşek, 2011, s.112). Bu çalışmada katılımcı olacak ortaokul öğrencilerini belirlemedeki ölçüt; "taşımalı eğitim uygulaması ile öğrenimlerini gerçekleştirmek" olarak ifade edilebilir. Bu doğrultuda, araştırmanın çalışma grubunu, Muğla ili Milas ilçesine bağlı bir köy okulunda 2020-2021 eğitim öğretim yılında ortaokul 5., 6., 7. ve 8. sınıf düzeylerinde öğrenim gören 20 öğrenci oluşturmaktadır. Katılımcı olarak her sınıf düzeyinden 5'er öğrenci seçilmiştir. Çalışma grubundaki bu öğrenciler köyde yaşamakta ve taşımalı eğitim ile öğrenimlerini devam ettirmektedirler. Büyük çoğunluğunun maddi imkânları yetersiz olup, aileleri tarafından tarla, bahçe ve hayvan bakımı gibi işlerde görevlendirilmektedir. Bu öğrencilerin çoğu kaynak kitaplara sahip değildir ve özel ders veya derslerine yardımcı bir eğitici tarafından yardımlar alamamaktadırlar. Çalışma grubunda yer alan ortaokul öğrencilerine ilişkin bilgiler Tablo 1' de verilmiştir. 
Tablo 1. Ortaokul Öğrencilerine Yönelik Demografik Bilgiler

\begin{tabular}{llll}
\hline Değişkenler & Grup & n & \% \\
\hline \multirow{2}{*}{ Cinsiyet } & Kız & 12 & 60 \\
& Erkek & 8 & 40 \\
\hline \multirow{3}{*}{ Sinnf Düzeyi } & 5 & 5 & 25 \\
& 6 & 5 & 25 \\
& 7 & 5 & 25 \\
Toplam & 8 & 5 & 25 \\
\hline
\end{tabular}

\section{Veri Toplama Araçlarn}

Araştırmada ortaokul öğrencilerinin görüşlerini belirlemek amacıyla yarı-yapılandırılmış görüşme formu kullanılmıştır. Görüşme soruları araştırmacı tarafından hazırlandıktan sonra uzmanların (1 fen eğitimcisi, nitel araştırma alanında 1 uzman ve 1 fen bilimleri öğretmeni) görüşüne sunulmuştur. Görüşler doğrultusunda düzenlenen form ile pilot çalışma yapılmıştır. Pilot çalışmada görüşme soruları 5 ortaokul öğrencisine uygulanmış ve sorularda gerekli değişiklikler ve düzeltmeler yapılmıştır. Ayrıca hazırlanan soruların yapı geçerliliğini sağlamak amacı ile fen eğitiminde ve uzaktan eğitim ile ilgili çalışmalar yapmış alan uzmanların yanı sıra ölçme ve değerlendirme uzmanının görüşlerine başvurulmuş ve forma son hali verilmiştir. Görüşme formunda toplam 7 adet açık-uçlu soru bulunmaktadır. Bu sorular ortaokul öğrencilerinin uzaktan eğitimde karşılaştıkları sorunlara, teknoloji kullanımına ilişkin yeterliliklerine, fen bilimleri dersinde karşılaştıkları sorunlara, fen bilimleri dersine yönelik bilişsel ve duyuşsal özelliklerindeki değişimlere ve sorunlara yönelik çözüm önerilerine ilişkin görüşlerini ortaya çıarmayı hedeflemektedir. Katılımclardan veri toplama süreci çevrimiçi ortamda (zoom çevrimiçi programı ile) gerçekleştirilmiştir. Tüm öğrenciler ve veliler, görüşmelerin kaydının yapılmasına izin vermis, böylece tüm verilerin ses kaydı alınmıştır. Her bir öğrenci ile Zoom uygulaması aracılığıyla bireysel görüşmeler gerçekleştirilmiştir. Yapılan görüşmeler ortalama 15 dakika sürmüştür.

\section{Verilerin Analizi}

Taşımalı eğitim ile öğrenim gören ortaokul öğrencileri ile gerçekleştirilen yarı-yapılandırılmış görüşme formundan elde edilen veriler içerik analizi yöntemi ile analiz edilmiştir. İçerik analizi, belli bir hacmi olan nitel materyali 
alarak temel tutarlılıkları ve anlamları belirlemeye ve anlamlandırmaya yönelik bir analiz tekniği olarak tanımlanabilir. İçerik analizi yoluyla bulunan temel anlamlara genel örüntüler ya da temalar denilebilir (Patton, 2014). Bu doğrultuda ilk olarak kayıtlar bilgisayara aktarılarak yazıya dökülmüştür. Ardından kodlar, kategoriler ve temalar oluşturulmuştur. Bu çalışmada, verilerden çıkarılan kavramlara göre yapılan kodlama kullanılmış; kodlamalar araştırma verilerine göre yapılmıştır. Daha sonra veriler, ortaya çıkan kodlara göre belirli kategoriler altında toplanmış ve en son olarak kategoriler araştırmanın alt amaçları çerçevesinde temalandırılmıştır. Toplanan verilerin analizinde nitel analiz paket programı kullanılmıştır. Analizler sırasında öğrenciler "5.sınıf-Ö1", "6.sınıf-Ö4" şeklinde kodlanmış ve öğrencilerin cevaplarını çarpıcı bir şekilde yansıtmak amacıyla doğrudan alıntılara yer verilmiştir.

\section{Araştırmanın Geçerliği ve Güvenirliği}

Araştırmada elde edilen verilerin geçerlilik ve güvenirliğine ilişkin nitel araştırmalarda yapılması gerektiği vurgulanan "inandırıcılık", "aktarılabilirlik" ve "tutarlık" kavramları doğrultusunda işlemler gerçekleştirilmiştir. Bu bağlamda araştırmanın inandırıcılığın sağlanması amacıyla çalışma biri nitel araştırma, biri uzaktan eğitim ve biri fen eğitiminde alan uzmanları olmak üzere uzman incelemesine sunulmuştur. İgili uzmanlar yapılan bu çalışmayı, araştırmanın deseni, veri toplama ve analiz, sonuçlara ulaşma ve yorum aşamaları açısından incelemişler ve çeşitli önerilerde bulunmuşlardır. Araştırma sonuçlarının aktarılabilirliğine yönelik öğrencilerin görüşlerinden doğrudan alıntılar yapılarak ayrıntılı betimleme yöntemine başvurulmuştur. Son olarak ise araştırmanın nitel verilerinin güvenirliğine ilişkin "tutarlık" kavramı çerçevesinde nitel araştırmalar konusunda uzman bir kişi araştırmaya dışarıdan bir gözle bakarak veri toplama araçlarının oluşturulması, verilerin toplanması, analizi ve kodlanması sürecindeki kavramsallaştırma yaklaşımındaki araştırmacıların tutarlığına yönelik incelemeler gerçekleştirmiştir. Bu incelemeler doğrultusunda araştırmacı tarafından gerekli düzenlemeler yapılmıştır. 


\section{Etik Kurul İzin Bilgileri}

Bu araştırma, Muğla Sıtkı Koçman Üniversitesi İnsan Araştırmaları Etik Kurulu'nun 05.01.2021 tarih ve 04 sayılı kararı ile etik açıdan uygun bulunmuştur.

\section{Bulgular}

Taşımalı eğitim ile öğrenim gören ortaokul öğrencileri ile yapılan görüşmelerden elde edilen verilerin içerik analizi sonucunda uzaktan eğitimde fen bilimleri dersi teması ve bu temaya ilişkin beş alt temaya ulaşılmıştır. Ortaya çıkan tema, alt temalar ve kodlar Şekil 1'de gösterilmiştir.

\section{UZAKTAN EĞİTİMDE FEN BIILIMLERİ DERSİ}
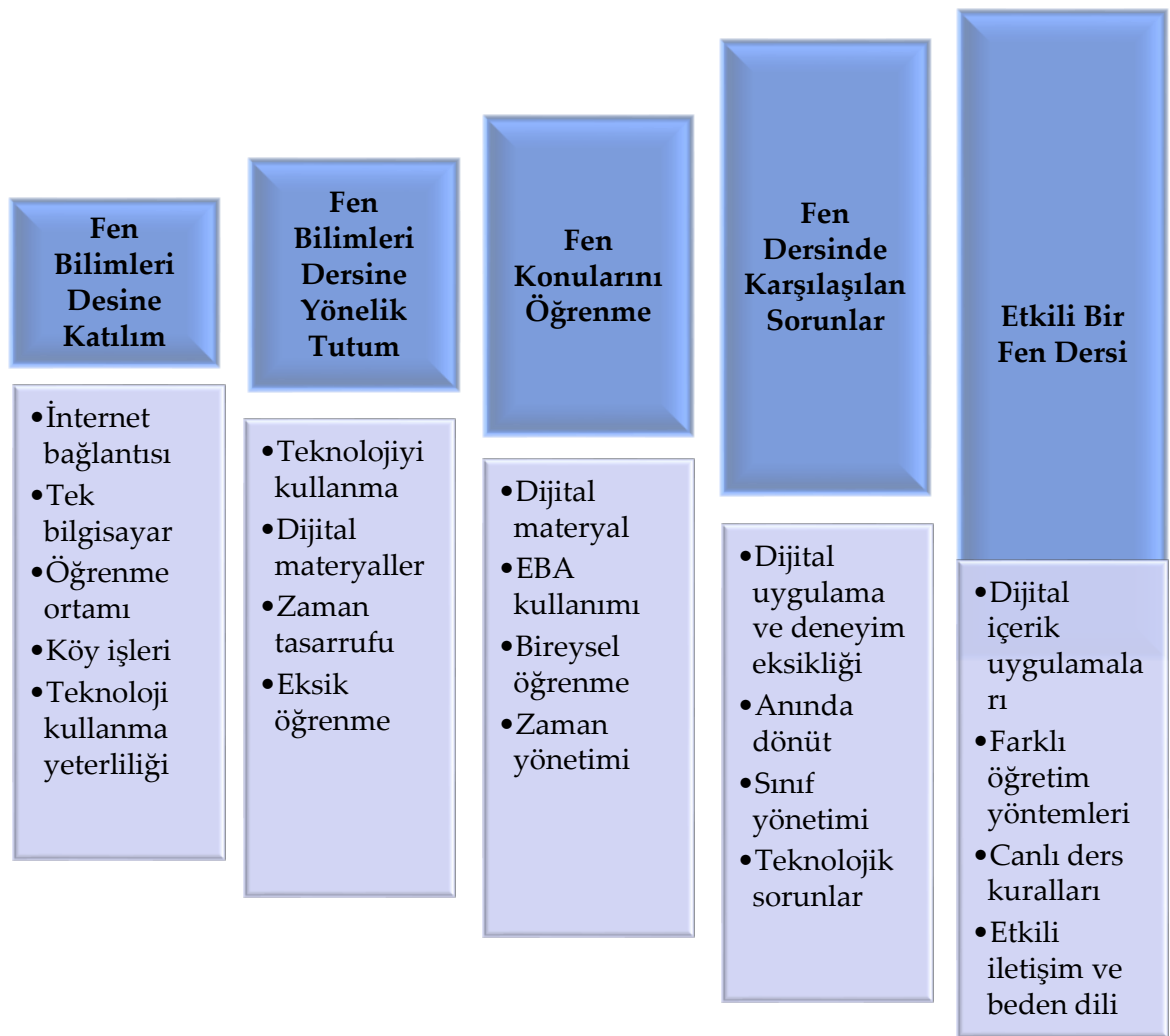

Şekil 1. Taşımalı Öğrencilerin Fen Bilimleri Dersine Yönelik Görüşler İçin Temalar ve Kodlar 


\section{Uzaktan Eğitimde Fen Bilimleri Derslerine Katılım}

Pandemi döneminde Mart-2020'den itibaren Fen Bilimleri dersine ortaokul öğrencileri uzaktan eğitim kapsamında çevrimiçi ortamlarda katılabilmektedirler. Taşımalı eğitim ile öğrenim gören öğrenciler fen bilimleri derslerine çoğunlukla zamanında katılabildiklerini, kısmen ise internet bağlantısı, tek bilgisayara sahip olma, ders çalışma ortamlarının uygun olmaması ve köy işlerinin olması gibi nedenlerden dolayı fen bilimleri derslerine katılamadıklarını ifade etmişlerdir. Ayrıca ilgili derse katılabilmede teknoloji kullanma yeterlilikleri üzerine de görüşler belirtmişlerdir. Öğrencilerin ilgili alt temaya ilişkin görüşleri doğrultusundaki kodlar aşağıda açıklanmıştır.

Internet bağlantısı: Köylerde ikamet eden ortaokul öğrencileri uzaktan eğitim ile verilen fen bilimleri derslerine kısmen internet bağlantılarının kesilmesi, yavaşlaması veya elektrik kesintileri gibi nedenlerden dolayı zamanında katılamadıklarını ifade etmişlerdir. Öğrenci görüşlerinden bazılarına aşağıda yer verilmiştir:

- "Fen derslerine katılacağım zaman bazen internet kesiliyor." (5.sınıf-Ö3)

- "Köyde olduğumuzdan internet çok yavaş." (7.sinif-Ö4)

- "Bazen elektrik kesiliyor ve ben fen derslerine giremiyorum." (8.sinif-Ö5).

Tek bilgisayar: Öğrenciler evlerinde tek bilgisayar olduğunu ve uzaktan eğitim ile verilen fen derslerinin diğer kardeşlerinin derslerinin aynı saatte olmasından dolayı derslerine bazen zamanında giremediklerini ifade etmişlerdir. Öğrenci görüşlerinden bazılarına aşağıda yer verilmiştir:

- "Bir tane bilgisayarmı var ve kardeşlerimin de dersleri olduğunda fen derslerine giremiyorum." (5.sınif-Ö4)

- "Ü̈ç kardeşim var, derslerimiz bazen çakışıyor." (6.sinıf-Ö3)

- "Kardeşlerimin dersleriyle benim dersim çakışıyor. Evde başka bilgisayar olmadığından fen dersine giremiyorum." (7.sinıf-Ö2)

Öğrenme ortamı: Öğrenciler uzaktan eğitim ile verilen fen derslerine katılabilmek için kalabalık bir ailelerinin olmalarından dolayı uygun öğrenme ortamlarının olmadığını ifade etmişlerdir. Öğrenci görüşlerinden bazılarına aşağıda yer verilmiştir: 
- "Evimizde fen derslerine katılma veya fen dersine çalı̧̧mak için bana ait bir odam yok." (6.sinif-Ö3)

- "Kalabalı bir evimiz var, canlı derslere katılmada çok uygun bir ortama sahip değilim." (7.sınıf-Ö3)

Köy işleri: Öğrenciler bahçe, tarla ve hayvan bakımı gibi bazı işlerden dolayı fen bilimleri canlı derslere zamanında katılamadıklarını ifade etmişlerdir. Öğrenci görüşlerinden bazılarına aşağıda yer verilmiştir:

- "Bazen ders zamanlarinda hayvanlarmizin bakıminda aileme yardım etmek zorunda kahyorum." (8.sinif-Ö2)

- "Tarla veya bahçe işleri olduğundan derslere giremiyorum." (7.sınıf-Ö5)

Teknoloji kullanma yeterliliği: Öğrenciler pandemi döneminin başlarında yapılan canlı fen derslerine katılmada teknolojiyi ilk defa kullanmalarından dolayı zorluklar yaşadıklarını ve bazen canlı fen derslerine girişlerde ID veya şifre gibi sorunlarla karşılaştıklarını ifade etmişlerdir. Ayrıca öğrenciler bu sorunlara yönelik öğretmenleri veya ebeveynleri tarafından çözüm yolları gösterildiğinde bir daha benzer sorunlarla karşılaşıldığında kendilerinin hemen çözdüklerini belirtmişlerdir. Öğrenci görüşlerinden bazılarına aşağıda yer verilmiştir:

- "Teknolojiyi çok iyi kullanabiliyorum. Canlı fen derslerine katılmada yaşadığım sorunları kendim çözüyorum." (6.sınıf-Ö2)

- "Teknolojiyi artık iyi kullandığımı düşünüyorum." (7.sınıf-Ö1)

- "Canlı derslere girerken artık teknoloji ile ilgili sorunlar kendim çözüyorum." (8.sinif-Ö5)

\section{Uzaktan Eğitimde Fen Bilimleri Dersine Yönelik Tutum}

Ortaokul öğrencilerinin uzaktan eğitim ile verilen fen bilimleri dersine yönelik olumlu tutumlara sahip oldukları görülmektedir. Bu durumun nedenleri olarak ise teknolojiyi kullanma, dersleri dijital materyaller ile işleme ve zamandan tasarruf elde etmelerini belirtmiş̧lerdir. Ayrıca öğrenciler bazen fen derslerine katılamadıklarını ve işlenen konuları öğrenemediklerini, bu durumunda fen dersine yönelik tutumlarını olumsuz etkilediklerini ifade etmişlerdir. Öğrencilerin ilgili alt temaya ilişkin görüşleri doğrultusundaki kodlar aşağıda açıklanmıştır. 
Teknolojiyi kullanma: Öğrenciler uzaktan eğitim sayesinde bir bilgisayara ve internet bağlantısına sahip olduklarını ve böylece daima teknolojiyi kullanabildiklerini ve derse motive olduklarını ifade etmişlerdir. Ayrıca öğrenciler fen dersi ile ilgili bütün ödev, proje ve uygulamaları da teknoloji ile severek yaptıklarını belirtmişlerdir. Öğrenci görüşlerinden bazılarına aşağıda yer verilmiştir:

- "Fen dersi ile ilgili her şeyi bilgisayardan yapıyorum. Bu durum çok hoşuma gidiyor." (5.sinuf-Ö3)

- "Fen ödevlerimi bilgisayardan yapıyorum. Öğretmen bize uygulamal ödevler veriyor. Teknolojiyi kullanarak yapmak çok güzel." (7.sınıf-Ö)

Dijital materyaller: Öğrenciler canlı fen derslerinde öğretmenlerinin video, animasyon, belgesel gibi dijital materyaller kullandığını ve bu durumun fen dersini sevmelerine yol açtı̆̆ını ifade etmişlerdir. Öğrenciler fen derslerinde görsel ve işitsel materyaller de kullandıklarını, çevrimiçi soru çözümleri gerçekleştirdiklerini belirtmişlerdir. Ayrıca fen derslerinin bu şekilde işlenmesinin çok hoşlarına gittiğini, konuları daha iyi anladıklarını ve zevkli bir öğrenme ortamı oluştuğunu vurgulamışlardır. Öğrenci görüşlerinden bazılarına aşağıda yer verilmiştir:

- "Fen derslerinde video ve animasyon izliyoruz. Konuları böyle işlemek çok zevkli oluyor." (6.sinif-Ö3)

- "Fen dersinde konularnn görsel gösterimleri çok hoşuma gidiyor." (7.sınıf-Ö2)

- "Fen dersinde çeorimiçi sorular çözüyoruz. Bu şekilde çok soru çözmü̈s oluyoruz. Fen dersini seviyorum." (8.sinif-Ö5)

Zaman tasarrufu: Taşımalı eğitim ile öğrenim gören öğrenciler uzaktan eğitim döneminde güne erken başlamadıklarını ve servis kullanmadıklarını belirterek, bu durum sayesinde zamandan tasarruf ettiklerini ifade etmişlerdir. Öğrenciler kendilerine kalan zamanı ise fen dersi ile ilgili dijital çalışmalar, ödevler veya uygulamalar kullanarak geçirdiklerini ve artık fen derslerini daha çok sevdiklerini vurgulamışlardır. Öğrenci görüşlerinden bazılarına aşağıda yer verilmiştir:

- "Artık erken kalkmiyorum. Uykumu alıyorum. Dinç bir şekilde canlı fen derslerine katılıyorum. Bu da derse ilgi duymamı arttırıyor." (5.sınıf-Ö1)

- "Servise çok erken biniyorduk ve derslere uykulu giriyorduk. Şimdi ise fen derslerine zevkle katıliyorum." (7.sinif-Ö4) 
Eksik öğrenme: Öğrenciler bazen canlı fen derslerine internet kesintisi, köy işlerine yardıma gitmeleri gibi durumlardan dolayı katılamadıklarını ve bazı konuları öğrenemediklerini belirtmişlerdir. Bu durumun ise kendilerinde fen ile ilgili eksik öğrenmeler oluşturduğunu, sonraki derslerdeki konuları öğrenmede zorlanmalarına neden olduğunu ifade etmişlerdir. Öğrenciler böyle bir durum karşısında ise fen derslerine katılmak istemediklerini vurgulamışlardır. Öğrenci görüşlerinden bazılarına aşağıda yer verilmiştir:

- "Internet bağlantısı gittiğinde canlı fen dersine giremiyorum ve konular kaçırıyorum. Böyle olunca sonraki fen derslerine giresim gelmiyor." (7.sinıf-Ö3)

- "Köy işlerini yaparken de canli fen derslerine giremiyorum. Konular kaçırınca fen dersini sevmiyorum."(8.sinıf-Ö1)

\section{Uzaktan Eğitimde Fen Konularının Öğrenimi}

Ortaokul öğrencileri uzaktan eğitim ile verilen fen bilimleri dersinde işlenen konuları anlayabildiklerini ve öğrenebildiklerini ifade etmişlerdir. Öğrenciler bu duruma neden olarak derslerde video, animasyon gibi dijital materyal kullanımının yanı sıra, dijital kaynak ve test soru çözümlerinin yapılması ve etkili EBA kullanımını belirtmişlerdir. Ayrıca öğrenciler fen derslerine yönelik bireysel öğrenmeler gerçekleştirdiklerini ve bu yönde zamanlarını iyi kullandıklarını vurgulamışlardır. Öğrencilerin ilgili alt temaya ilişkin görüşleri doğrultusundaki kodlar aşağıda açıklanmıştır.

Dijital materyal: Öğrenciler canlı fen derslerinde video, film, animasyon gibi dijital materyallerin yanı sıra konu öğretimlerine yönelik dijital kaynak ve çevrimiçi soru çözümlerinin yapıldığını ve kullanıldığını ifade etmişlerdir. Böylece fen konularını daha iyi anladıklarını vurgulamışlardır. Öğrenci görüşlerinden bazılarına aşağıda yer verilmiştir:

- "Fen derslerinde konu ile ilgili video izleyince daha iyi anlıyorum." (5.sinif-Ö4)

- "Fen konularında görsel materyal kullanıyoruz." (6.sınıf-Ö3)

- "Çeorimiçi soru çözümleri konunun pekişmesini sağlıyor." (8.sınıf-Ö4)

EBA kullanımı: Öğrenciler EBA'nın zengin bir fen içeriğine sahip olduğunu ve konular ilgili çok fazla video içerdiğini ifade etmişlerdir. EBA kullanımı ile fen konularını daha iyi anladıklarını belirtmişlerdir. Öğrenci görüşlerinden bazılarına aşağıda yer verilmiştir: 
- "EBA'ya her zaman giriyorum ve anlamadığım fen konuları hakkında araştırma yapıyorum." (6.sinıf-Ö3)

- "EBA'da fen ile ilgili her şey var. Konularm tekrarm video izleyerek veya soru çözerek yapabiliyorum." (8.sınıf-Ö1)

Bireysel öğrenme: Öğrenciler fen konularında anlaşılmayan veya eksik öğrenilen yerleri internet aracılığıyla EBA ya da youtube gibi web sayfalarındaki konu anlatımı videolar aracıllğ̆ıyla giderdiklerini ifade etmişlerdir. Bir bakıma öğrenciler kendi öğrenmelerinde bireysel öğrenme ihtiyaçlarını belirleyerek çözümler elde etmeyi öğrenmişlerdir. Öğrenci görüşlerinden bazılarına aşağıda yer verilmiş̧ir:

- "Fen ile ilgili anlamadığım yerleri youtube'dan konu anlatımı video izleyerek anlamaya çalışıyorum." (7.sınif-Ö2)

- "Bazı kavramları tam kafamda anlamlandıramıyorum, bunun için videolar izliyorum ve anliyorum." (8.sinif-Ö2)

Zaman yönetimi: Öğrenciler yüz yüze yapılan eğitimlerde fen derslerinde bir konuyu tam anlamadan dersin bittiğini, şimdi ise derslerde videolar, sunumlar, anlatımlar yapılmasına rağmen zamanın yettiğini ifade etmişlerdir. Yani öğrenciler uzaktan verilen fen derslerinde zamanın etkili kullanılarak etkili öğrenmeler gerçekleştiğini belirtmişlerdir. Öğrenci görüşlerinden bazılarına aşağıda yer verilmiştir:

- "Fen derslerinde video izleme, sunum izleme, konu anlatımı gibi bir sürü şey yapılıyor ve ders bitiyor. Önceden bunları ögretmen yapamadan ders biterdi. Bu şekilde daha iyi öğreniyorum." (7.sınıf-Ö3)

- "Fen bilimleri öğretmenimiz fen dersinde bizim öğrenmemiz için EBA'dan veya youtube'dan videolar gösteriyor. Böyle daha iyi öğreniyorum."(8.sinif-Ö4)

\section{Uzaktan Eğitimde Fen Bilimleri Dersinde Karşılaşılan Sorunlar}

Ortaokul öğrencileri uzaktan eğitim ile verilen fen bilimleri dersinde ve genel olarak çeşitli sorunlarla karşılaştıklarını ifade etmişlerdir. Bu sorunları dijital uygulama eksikliği veya deneyim eksikliği, teknolojik sorunlar, anında dönüt ve sınıf yönetimi olarak belirtmişlerdir. Öğrencilerin ilgili alt temaya ilişkin görüşleri doğrultusundaki kodlar aşağıda açıklanmıştır. 
Dijital uygulama ve deneyim eksikliği: Öğrenciler canlı fen derslerinde öğretmenin uygulamış olduğu dijital materyalleri veya uygulamaları ders sonrasında da kendilerinin uygulamak istediklerini, ancak ilk defa kullandıkları için uygulayamadıkların ifade etmişlerdir. Bu durumda bu tür uygulamalara yönelik tanıtıcı videoların olması gerektiğini vurgulamışlardır. Öğrenci görüşlerinden bazılarına aşağıda yer verilmiştir:

- "Öğretmenimiz derslerde bazen Kahoot uygulamasını kullanıyor. Bende kullanmak istedim ama başaramadım." (8.sınıf-Ö4)

- "Fen derslerinde bazen öğretmenimiz kodlama yapıyor ama nasıl yapıldığıı bize göstermedi. Öğrenmek isterim."(8.sinıf-Ö1)

- "Bu uygulamalarm nasıl kullamildı̆ım gösteren videolar çekilse iyi olur." (8.s1nif-Ö3)

Anında Dönüt: Öğrenciler canlı fen derslerinde konu ile ilgili öğretmene soru sormak ve anında dönüt almak istediklerini, ancak bunda başarılı olamadıklarını belirtmişlerdir. Öğrenci görüşlerinden bazılarına aşağıda yer verilmiştir:

- "Anlamadiğırm yerleri öğretmenime sormak istiyorum." (6.sınıf-Ö1)

- “Öğretmenimizden hemen dönüt alamıyoruz." (6.sinıf-Ö3)

Sınıf yönetimi: Öğrenciler canlı fen derslerinde soru çözümünde kargaşa olduğunu ve seslerin birbirine karıştığını, öğretmen ders anlatırken bazı öğrencilerin mikrofonu açık olduğundan gürültü olduğunu ifade etmişlerdir. Bu duruma fen bilimleri öğretmenlerinin müdahale etmediğini de vurgulamışlardır. Öğrenci görüşlerinden bazılarına aşağıda yer verilmiştir:

- "Fen derslerinde çok gürültü oluyor." (8.sınif-Ö2)

- "Bazı arkadaşlarım derslerde devaml bir şeyler söylüyor, öğretmenimi anlayamıyorum. Öğretmenimiz mikrofonu açık olanlara bir şey demiyor." (8.sınıf-Ö3)

Teknolojik sorunlar: Öğrenciler uzaktan eğitimde verilen canlı derslere katılmada internet kesintisi veya yavaşlaması gibi sorunların yanı sıra bilgisayarlarının bozulması, ses gitmeme veya alamama gibi durumlarla karşılaştıklarını belirtmişlerdir. Öğrenci görüşlerinden bazılarına aşağıda yer verilmiştir: - "Bazen internetim kesiliyor veya yavaşlyyor, derslere giremiyorum."(5.sinif-Ö2)

- "Derslerde ses gelmiyor." (6.sınıf-Ö1) 


\section{Uzaktan Eğitimde Etkili Bir Fen Dersi}

Ortaokul öğrencileri uzaktan eğitimde etkili bir fen bilimleri dersi için deney uygulamaları, ek dijital kaynak, online soru çözümleri, video, animasyon, film vb dijital içerik uygulamalarının kullanımlarının, düz anlatım dışında farklı öğretim yöntemlerinin kullanımlarının, öğretmenin etkili iletişim ve beden dili kullanımlarının, canlı ders kurallarının kullanımlarının olması gerektiğini ifade etmişlerdir. Öğrencilerin ilgili alt temaya ilişkin görüşleri doğrultusundaki kodlar aşağıda açıklanmıştır.

Dijital içerik uygulamaları: Öğrenciler etkili bir canlı fen derslerinde deney uygulamalarının, dijital kaynakların, online soru çözümlerinin, dijital tahta, video, animasyon gibi dijital içerik uygulamalarını olması gerektiğini belirtmişlerdir. Bir bakıma fen derslerinde web 2.0 araçlarının kullanımına vurgu yapmışlardır. Öğrenci görüşlerinden bazılarına aşağıda yer verilmiştir:

- "Canlı fen derslerinde öğretmenimizin deney yapmasın isterim." (5.sınıf-Ö2)

- "Fen öğretmenimiz derslerde dijital tahtayı kullansin." (6.sını-Ö1)

- "Bize fen ile ilgili dijital kaynaklar gönderebilir." (7.sınıf-Ö3)

Farklı öğretim yöntemleri: Öğrenciler fen bilimleri öğretmenlerinin sunum ve düz anlatım yöntemi dışında da farklı bir şekilde dersi işleyebileceklerini ifade etmişlerdir. Öğrenci görüşlerinden bazılarına aşağıda yer verilmiştir:

- "Fen bilimleri öğretmenimiz çoğunlukla sunum yapıyor." (7.sinıf-Ö3)

- "Düz anlatım dışında da dersi anlatsa iyi olur." (8.sınıf-Ö2)

Canlı ders kuralları: Öğrenciler derslerde kendilerinin de konuşması ile birlikte seslerin birbirine karıştı̆̆ını, öğretmene soru soramadıklarını ve anlayamadıkları yerleri belirtemediklerini ifade etmişlerdir. Bu doğrultuda canlı derslerde bazı kuralların olması gerektiğini vurgulamışlardır. Öğrenci görüşlerinden bazılarına aşağıda yer verilmiştir:

- “Öğretmenimize soru sorarken herkes konuşuyor, sesler karıştığından bir şey anlamıyorum." (6.sinif-Ö5)

- "Canlı derslerde bazı kurallar olsa iyi olur." (7.sinif-Ö1)

Etkili iletişim ve beden dili: Öğrenciler fen bilimleri öğretmenlerinin konuyu anlatırken tek düze bir ses tonuyla anlattıklarını ve hep aynı beden dilini kullandıklarını ifade etmişlerdir. Ayrıca öğretmenleriyle ders anlatırken iletişim 
kuramadıklarını, söylemek istediklerini sohbet kısmına yazdıklarını belirtmişlerdir. Öğrenci görüşlerinden bazılarına aşağıda yer verilmiştir:

- "Fen bilimleri öğretmenimiz hep aynı ses tonunu kullanıyor." (7.sınıf-Ö5)

- "Öğretmenimize soru sormak için sohbet kısmını kullanıyoruz. Bunu yapmak çok zor ve zaman alıyor." (8.sinif-Ö2)

\section{Tartışma, Sonuç ve Öneriler}

Çalışmada taşımalı eğitim uygulaması ile farklı sınıf düzeylerinde öğrenim gören ortaokul öğrencilerinin pandemi döneminde uzaktan eğitimle verilen fen bilimleri dersine ilişkin görüşleri incelenmiştir. Bu doğrultuda çalışma sonucunda çeşitli sonuçlar elde edilmiştir.

Araştırmanın birinci sonucunda, taşımalı eğitim ile öğrenim gören öğrencilerin uzaktan eğitim ile verilen fen bilimleri dersine katılmada çeşitli sorunlarla karşılaştıkları tespit edilmiştir. Bu bağlamda öğrenciler, internet bağlantısı ve alt yapısı gibi donanımsal sorunlar yaşadıkları, tek bilgisayara sahip olma ve ailelere köy işlerinde yardım etme gibi durumlarla karşılaştıkları belirlenmiştir. Bu sonuca göre öğrencilerin ailelerine yardım etmek durumunda kalmaları onların uzaktan eğitime devam etmelerini olumsuz etkilediği söylenebilir. Aynı zamanda yaşadıkları yerde internet altyapısının olmaması onların uzun süre uzaktan eğime devam edememelerine ve dersleri anlamakta zorluk çekmelerine neden olmuştur. Benzer şekilde, Kürtüncü ve Kurt (2020), öğrencilerin uzaktan eğitimde karşılaştıkları sorunları araştırmışlardır. Bu çalışmaya göre öğrenciler alt yapı koşullarını yetersiz bulduklarını, aynı anda birçok öğrencinin sisteme girmeye çalışmasıyla internet erişiminde sorunlar yaşadıklarını ve derslerini takip etmekte zorlandıklarını belirtmişlerdir.

Araştırmanın ikinci sonucunda, taşımalı eğitim ile öğrenim gören öğrencilerin uzaktan eğitim ile verilen fen bilimleri dersine yönelik olumlu tutumlara sahip oldukları belirlenmiştir. Araştırmaya katılan öğrenciler bu durumun nedeni olarak teknolojiyi kullanma, dersleri dijital materyaller ile işleme ve zamandan tasarruf elde etmeleri şeklinde ifade etmişlerdir. Buna bağlı olarak fen derlerinde daha fazla teknolojiyi kullanmanın, derslerin içeriğini dijital anlamda zenginleştirmenin ve uzaktan eğitim sürecinde taşımalı öğrencilerin zamandan tasarruf etmelerinin fene yönelik olumlu tutum sağladığ1 söylenebilir. Bununla ilgili olarak Savaş ve Karataş (2019), günümüz öğrencilerinin $\mathrm{Z}$ kuşağı öğrencileri olması nedeniyle, eğitim öğretim ortamlarının 
teknolojiden, internetten ve dijital yapıdan bağımsız yürütülmesinin mümkün olmayacağını belirtmişlerdir.

Araştırmanın üçüncü sonucunda, taşımalı eğitim ile öğrenim gören öğrencilerin uzaktan eğitim ile verilen fen bilimleri dersinde işlenen konuları anlayabildikleri ve öğrenebildikleri tespit edilmiştir. Araştırmaya katılan öğrenciler bu durumun nedeni olarak derslerde video, animasyon gibi dijital materyal kullanımının yanı sıra, dijital kaynak ve test soru çözümlerinin yapılması ve EBA kullanımının gerçekleştirilmesinin etkili olduğunu belirtmişlerdir. Öte yandan dijital ortamda, Z kuşağı öğrencilerinin dijital yetkinliklerini göz önünde bulundurarak, online soru çözmek, video gösterimlerine daha fazla yer vermek, hatta güvenlik, malzeme ve zaman sıkıntısı yaşamadan bilgisayar ortamında deneyleri yapmak öğrencilerin fen konularını anlamalarını sağlamıştır. Benzer şekilde Dönel Akgül ve Kılıç (2020), dijital ortamda eğitim platformların geliştirilmesinin $Z$ kuşağı için önem taşıdığını, bu bireylerin geleneksel öğrenmeye göre, öyküleştirme, oyuna çevirme ve hayallerle akılda tutmayı sağlayacak öğrenmeyi tercih ettiklerini ifade etmişlerdir.

Araştırmanın dördüncü sonucunda, taşımalı eğitim ile öğrenim gören öğrencilerin uzaktan eğitim ile verilen fen bilimleri dersinde dijital uygulama eksikliği veya deneyim eksikliği, teknolojik sorunlar, anında dönüt ve sınıf yönetimi gibi çeşitli sorunlar yaşadıkları belirlenmiştir. Araştırmaya katılan öğrenciler ilk defa karşılaştıkları dijital materyallerin kullanımı ve internet kesintisi veya yavaşlaması gibi teknolojik ve donanımsal sorunlarla karşılaştıklarını belirtmişlerdir. Bu sonuçlar, Şentürk, Duran ve Yılmaz (2020)'ın yaptıkları çalışma ile benzerlik göstermektedir. Çalışmalarında uzaktan eğitim sürecinde öğrencilerin sistem alt yapısı, video ve ses gibi teknolojik sorunlar yaşadıklarını tespit etmişlerdir. Öte yandan Özaydın Özkara (2020), öğrencilerin çoğunlukla internet kaynaklı sıkıntı yaşadıklarını ifade etmişlerdir. Ayrıca öğrenciler canlı fen derslerinde konu ile ilgili öğretmene soru sormak ve anında dönüt almak istediklerinde alamadıklarını belirtmişlerdir. Bu durumun nedeni olarak uzaktan eğitim ile verilen derslerin kısıtlı sürede fazla öğrenciye verilmesinden kaynaklandığı söylenebilir. Benzer şekilde Aydın (2020), ders sürelerinin kısa olmasına bağlı olarak öğrencilerin konuları iyi kavrayamadıklarını tespit etmiştir. 
Araştırmanın beşinci sonucunda, taşımalı eğitim ile öğrenim gören öğrencilerin uzaktan eğitimde etkili bir fen bilimleri dersine yönelik deney uygulamaları, ek dijital kaynak, çevrimiçi soru çözümleri, video, animasyon, film vb dijital içerik uygulamalarının kullanımlarının olması gerektiğini ifade etmişlerdir. Ayrıca öğrenciler bu tür dijital uygulamaların düz anlatım dışında farklı öğretim yöntemlerinin kullanımları ile gerçekleştirilerek zengin bir öğrenme ortamı oluşturularak yapılmasını belirtmişlerdir. Bu sonucun nedeni olarak Z kuşağı öğrencilerinin teknolojinin içinde büyüyor olmaları (Bulgan ve Göktaş, 2016) gösterilebilir. Ayrıca katılımcılar etkili bir fen eğitiminde öğretmenin etkili iletişim ve beden dili kullanmaları ve canlı ders kurallarının olması gerektiğini ifade etmişlerdir. Benzer şekilde uzaktan eğitimde öğretmenin dikkat etmesi gereken durumlardan birisi de iletişimdir. Öğretmenler, uzaktan eğitim sürecinin öğrenci adına verimli olması için iyi bir etkileşimin olmasını gerektiğini ifade etmişlerdir ( Başaran vd., 2020).

$\mathrm{Bu}$ araştırmanın sonuçları doğrultusunda, taşımalı eğitim ile öğrenim gören öğrenciler açısından, uzaktan eğitimin zorunlu durumlarda çözüm olarak kullanılabilmesi önerilmektedir. Ülkemizde her bölgenin coğrafi şartlarının farklı olmasına bağlı olarak, özellikle kış şartlarının çok ağır geçtiği yerlerde taşımalı sistemde olan öğrencilerin ağır şartlardan dolayı okula ulaşamaması durumunda uzaktan eğitim kullanılabilir. Ayrıca bu tür öğrencilerin teknolojik alt yapı ve sorunlarının giderilmesi, ailelerin uzaktan eğitim sürecine yönelik uygun ortam oluşturmaları konusunda bilinçlendirilmeleri önerilmektedir. Öte yandan uzaktan eğitimde fen bilimleri dersinde etkili bir öğretim sürenin gerçekleştirilebilmesi amacıyla video, animasyon, belgesel vb. dijital materyal ve kaynak kullanılması, dijital deneylerin yapılması ve bu derslerde çağdaş öğretim yöntem ve tekniklerin kullanılması önerilmektedir.

Ayrıca günümüz dünyasında öğrencilerin uzaktan eğitime ve teknolojiye adapte olmaları avantaja çevrilerek, öğrencilere çeşitli bilgisayar programları öğretilip derslerde kendi içeriklerini üretmeleri önerilebilir. Bu ise onların derse güdülenmelerini arttırıp bilgiyi kendilerinin yapılandırmalarını sağlayarak akademik başarılarını arttırabilir. Öte yandan özellikle coğrafi koşullarının ağır olduğu bölgelerde taşımalı olarak okula devam eden öğrencilerin, okula gidemedikleri günlerde meydana gelebilecek konu eksiklerinin tamamlanabilmesi için uzaktan eğitim çözüm olarak kullanılabilir. 


\section{EXTENDED ABSTRACT}

\section{The Opininons of Bussed Education Students About Science Lessons Given With Ditance Education During Covid-19 Pandemic \\ Sinem Karataş Öztürk \\ Milli Eğitim Bakanlığı}

In December 2019, an unknown pneumonia was detected in Wuhan City of China and was firstly reported to the World Health Organization (WHO) Country Office in 31December 2019. On 11 February, WHO declared the name of "COVID-19" for coronavirus disease. After these events, the virus has spread rapidly, and all world countries has become obliged to take precautions in many sectors especially in educational services. In our country along with the first case in March 2020, education was suspended. Subsequently, in all educational levels from pre-school to higher education, teachers and students have started to carry out their lessons by way of distance education. This period has continued in many aspects and the students from all strata have not been away from education. There are different definitions of distance education. İşman (2008) defined distance education as an education system model in which students and teachers in different learning environments perform teaching activities, communication technologies and services. According to Uşun (2006), distance education; it is a systematic technology application in which the source and the receiver are distant in the learning-teaching process, communication and interaction is provided by advanced technologies.

Distance education is important for many people and it provides equal opportunity in education. Disabled people, young children, those who cannot go to school for various reasons, and those who want to improve themselves in various fields can benefit from distance education (Y1ld1z, 2004). Thanks to distance education, the cost of education can be reduced. It can also liberate the student by providing individual learning. With rich content, learning can be achieved without being in a certain time and place. Many people can benefit from one person at a time (Akyürek, 2020). When considered from this point of view, distance education can be considered as a short- 
term solution, especially when bussed students who are not schooled in their places of residence due to geographical conditions cannot attend school.

The purpose of this study is to find out the opinions of students in secondary schools benefitting from bussed education towards science lesson which was taught by way of distance education. In the study case study model, one of the qualitative research methods, was used. In case studies, one or more cases can be investigated deeply, factors of a situation (environment, individuals, events, processes, etc.) can be studied holistically, and these studies can focus on how they affect and be affected by the relevant situation (Yldirım \& Şimşek, 2011). The participants of the study consisted of 20 students studying at $5^{\text {th }}, 6^{\text {th }}$., $7^{\text {th }}$., and $8^{\text {th }}$ grades during 2020-2021 educational year in a village school of Milas district of Muğla. 5 students from each class level were chosen as a participant. Semi-structured interview form consisting of 7 questions was used to assess the views of students towards distance education process of science lesson. The interviews were conducted online. Each interview lasted for about 15 minutes. Content analysis was used to analyse the data. Firstly, interview records were transferred to the computer. After the records were transcribed; codes, categories and themes were created. The coding was made according to the concepts derived from the data. Then according to emerging codes, the data was collected under specific categories. Finally, categories were thematised within the frame of sub-goals of the study. For data analysis, a software for qualitative analysis was used.

In this study, the opinions of students who are studying in different grades of secondary schools and benefitting from bussed education about science lesson taught online during the pandemic were analysed. The results obtained from the study is as follows, respectively. First, it was assessed that the students benefitting from bussed education faced various problems in attending online science lessons. With this regard, it was determined that the students had some hardware problems such as internet connection and infrastructure and faced situations such as having only one computer and helping families with village works. Second, it was assessed that the students benefitting from bussed education had positive attitudes towards online science lessons. The students participating the study explained the reasons for this situation by pointing out the use of technology, learning the lessons digitally, and saving time. Third, it was discovered that the students benefitting from bussed education had picked up science lesson taught online. The students 
explained the reasons for this situation by drawing attention to solving tests, digital resources and effective use of EBA as well as utilizing digital resources such as video and animation in the lessons. Fourth, it was seen that the students benefitting from transported education faced various problems in online science lessons such as the lack of digital applications or experience and problems about technology, quick feedback, and classroom management. Fifth, the students benefitting from transported education stated that lessons should make use of digital content applications such as experiment applications, additional digital resources, online test solving, video, animation and film, etc. for effective online science lessons. According to the results of this research, considering the problems students having at transported education system, distance education can be used as a short-term solution especially in places having heavy winters. Additionally, it is proposed that technological infrastructure and problems should be solved and the awareness of families about preparing suitable environments for distance education process should be raised. Lastly, it is suggested that digital materials and resources such as video, animation, documentary, etc. should be used in distance education, digital experiments should be conducted, and contemporary teaching methods and techniques should be used in these lessons.

\section{Kaynakça / References}

Akyürek, M.İ. (2020). Uzaktan eğitim: Bir alanyazın taraması. Medeniyet Eğitim Araş̧trmalar Dergisi, 4(1), 1-9.

Aydın, E. (2020). Covid-19 döneminde eba tv üzerinden yapılan Türkçe derslerinin değerlendirilmesi. Milli Eğitim Dergisi, 49(1), 877-894. https//:dx.doi.org/ 10.37669/milliegitim.787592

Ayhün, S.E. (2013). Kuşaklar arasındaki farklılıklar ve örgütsel yansımaları. Ekonomi ve Yönetim Araştrrmalar Dergisi, 2(1), 93-112.

Ballıel Ünal, B. (2017). Web tabanlı uzaktan eğitimin fen bilimleri konularında öğrenci başarısına etkisi. Uluslararası Türk Ĕ̆itim Bilimleri Dergisi, 5(9), 481-490.

Bakioğlu, B. ve Çevik, M. (2020). COVID-19 pandemisi sürecinde fen bilimleri öğretmenlerinin uzaktan eğitime ilişkin görüşleri. Turkish Studies, 15(4), 109-129. https://dx.doi.org/10.7827/TurkishStudies.43502

Başaran, M., Doğan, E., Karaoğlu, E., ve Şahin, E. (2020). Koronavirüs (covid-19) pandemi sürecinin getirisi olan uzaktan eğitimin etkililiği üzerine bir çalışma. Academia Eğitim Araştırmaları Dergisi, 5(2), 368-397. 
Bostan Sarıoğlan, A., Altaş, R., ve Şen, R. (2020). Uzaktan eğitim sürecinde fen bilimleri dersinde deney yapmaya ilişkin öğretmen görüşlerinin araştırılması. Milli Eğitim Dergisi, 49(1), 371-394. https//:dx.doi.org/10.37669/milliegitim.787933

Bozkurt, A. (2017). Türkiye' de uzaktan eğitimin dünü, bugünü ve yarını. Açıköğretim Uygulamalan ve Araştırmalan Dergisi, 3(2), 85-124.

Bulgan, G. ve Göktaş, P. (2016). X, Y ve Z kuşağ engellerinin turizme erişebilirliğinin karşlaştırılması. Ekonomi ve Yönetim Araştırmaları Dergisi, 5(1), 24-49.

Çabuk Kaya, N. (2006). Taşımalı eğitim programındaki ilköğretim öğrencilerinin durumlarr: Silopi köyleri örneğinde bir sosyal değerlendirme. Ankara Üniversitesi Dil ve Tarih-Coğrafya Fakültesi Dergisi, 46(2), 105-116.

Daniel, S.J. (2020). Education and the Covid-19 pandemic. Prospects, 49, 91-96. https://doi.org/10.1007/s11125-020-09464-3

Dönel Akgül, G. ve Kılıç, M. (2020). Fen bilgisi öğretmen adaylarının eğitsel dijital oyunlar ve kodu uygulamasına yönelik görüşleri. Fen Bilimleri Öğgretimi Dergisi, 8(2), 101-120.

Elitaş, T. (2017). Uzaktan eğitim lisans sürecinde yeni iletişim teknolojileri: Atatürk üniversitesi uzaktan eğitim merkezi. Yayımlanmamıs doktora tezi. İstanbul: Marmara Üniversitesi Sosyal Bilimler Enstitüsü.

Etlioğlu, M. ve Tekin, M. (2020). Elektronik öğrenmede öğrenci tutum ve akademik başarı arasındaki ilişkide öğrenci merak ve kaygısının aracılık rolü. Selçuk Üniversitesi Sosyal Bilimleri Enstitüsü Dergisi, 2020(43), 34-48.

Gürbey, S., Ezberci Çevik E., veŞahin, A. (2020). Ilköğretimde yerleşik, taşımalı ve yatı bölge okullarında eğitim ve bu eğitimin öğrencilerin fen bilimleri dersine yönelik tutumları üzerine etkisi: Yahyalı ilçesi örneği. Batı Anadolu Eğitim Bilimleri Dergisi, 11(2), 445-459.

İşman, A. (2008). Uzaktan eğitim. Ankara: Pegem Akademi Yayıncllk.

Kapil, Y. ve Roy, A. (2014). A critical evaluation of generation $\mathrm{z}$ at workplaces. International Journal of Social Relevance \& Concern, 2(1), 10-14.

Kırık, A. M. (2014). Uzaktan eğitimin tarihsel gelişimi ve Türkiye'deki durumu. Marmara Illetişim Dergisi, 21, 73-94. https/:dx.doi.org/10.7829/midr.20142110299

Kürtüncü, M. ve Kurt, A. (2020). Covid-19 pandemisi döneminde hemşirelik öğrencilerinin uzaktan eğitim konusunda yaşadıkları sorunlar. Avrasya Sosyal ve Ekonomi Araştırmalar Dergisi, 7(5), 66-77.

Mishra, R.K., Sarkar, S., ve Singh, P. (2012). Today's HR for a sustainable tomorrow. New Delhi: Allied Publishers. 
Moore, J.L., Dickson-Deane, C., ve Galyen, K. (2011). E-learning, online learning and distance learning environments: Are they the same? Internet and Higher Education, 14(2), 129-135. https//:dx.doi.org/10.1016/j.iheduc.2010.10.001

Orhan, G. (2019). Taşımalı ve merkezi eğitim veren ortaokullardaki öğrencilerin müzik dersine yönelik metafor örneklerinin karşılaş̧trrlması (Şanlıurfa ili örneği). Yayımlanmamış yüksek lisans tezi. Malatya: İnönü Üniversitesi Eğitim Bilimleri Enstitüsü.

Ozan, Ö. (2008). Kursal eğitim ortamlarmm bilgi ve iletişim yoluyla iyileştirilmesi: Eskişehir taşımal ilköğretim uygulaması. Yayımlanmamış yüksek lisans tezi. Eskişehir: Anadolu Üniversitesi Sosyal Bilimler Enstitüsü

Özarslan, M., Kubat, B., ve Bay, Ö.F. (2007). Uzaktan eğitim için entegre ofis dersinin web tabanlı içeriğinin geliştirilmesi ve üretilmesi. IX. Akademik Bilişim Konferansı Bildiri Kitabı- 2007 içinde (s. 179- 187), Kütahya: Dumlupınar Üniversitesi.

Özaydın Özkara, B. (2020). Students' perspectives of distance education. Turkish Online Journal of Educational Technology, Special issue, 247-259.

Özer, M. (2020). Educational policy actions by the ministry of national education in the times of COVID-19. Kastamonu Education Journal, 28(3), 1124-1129. https://dx.doi.org/10.24106/kefdergi.722280

Özgün, A. (2007). İstanbul'da taşımahl eğitimin okul-veli-öğrenci açısından olumlu ve olumsuz etkileri .Yayımlanmamıs yüksek lisans tezi. İstanbul: Yeditepe Üniversitesi Sosyal Bilimler Enstitüsü.

Patton, M.Q. (2014). Qualitative research and evaluation methods integrating theory and practice. CA: Sage Publications.

Pınar, M.A. ve Dönel Akgül, G. (2020). The opinions of secondary school students about giving science courses with distance education during the covid-19 pandemic. Journal of Current Researches on Social Sciences, 10(2), 461-486. https//:dx.doi.org/10.26579/jocress.377

Sarı, H. İ. (2020). Evde kal döneminde uzaktan eğitim: Ölçme ve değerlendirmeyi neden karantinaya almamalıyız? Uluslararası Eğitim Araștrmaciarı Dergisi, 3(1), 121-128.

Sarıbaş, Ö., Kömürcü, S., ve Güler, E. (2016). Yavaş şehirlerde yaşayan Z kuşağının çevre ve sürdürülebilir kalkınma algiları: Seferihisar örneği. Uluslararası Türk Dünyası Turizm Araştırmaları Dergisi, 1(2), 107-119.

Savaş, S. ve Karataş, S. (2019). Z kuşă̆ı öğrencilerini tanımak. E. Kıral, E. Babaoğlan Çelik ve A. Çilek (Ed), Eğitim Araştırmaları (s. 227-241) içinde. Ankara: Eğitim Yöneticileri ve Uzmanlar Derneği Yayınları. 
Saykıll, A. (2018). Distance education: Definitions, generations, key concepts and future directions. International Journal of Contemporary Educational Research, 5(1), 2-17.

Somyürek, S. (2014). Öğretim sürecinde z kuşağının dikkatini çekme: Artırılmış gerçeklik. Eğitim Teknolojisi Kuram ve Uygulama, 4(1), 63-80.

Şentürk, Ş., Duran, V., ve Yilmaz, A. (2020). The secondary school students' opinions on distance education. Journal of Education and e-Learning Research, 7(4), 360-367. https//:dx.doi.org/10.20448/journal.509.2020.74.360.367

Şeren, N., Tut, E. ve Kesten, A. (2020). Korona virüs sürecinde uzaktan eğitim: Temel eğitim bölümü öğretim elemanlarının görüşleri. Turkish Studies- Educational, 15(6), 4507- 4524. https://dx.doi.org/10.47423/TurkishStudies.46472

Tanik-Önal, N. ve Önal, N. (2020). Teaching science through distance education during the Covid-19 pandemic. International Online Journal of Education and Teaching (IOJET), 7(4). 1898-1911.

Uşun, S. (2006). Uzaktan eğitim. Ankara: Nobel Yayınalık.

Yıldırım, A. ve Şimşek, H. (2011). Sosyal bilimlerde nitel araştırma yöntemleri. Ankara: Seçkin Yayınclik.

Yıldız, R. (2004). Öğretim teknolojileri ve materyal geliştirme. Ankara: Nobel Yayıncilık.

Yurdabakan, İ. ve Tektaş, M. (2013). Taşımalı ilköğretim öğrencilerinin taşımalı eğitime ilişkin görüşleri. Dokuz Eylül Üniversitesi Sosyal Bilimler Enstitüsü Dergisi, 15(3), 511-527.

\section{Kaynakça Bilgisi / Citation Information}

Karataş Öztürk, S. (2021). Covid-19 salgını sürecinde taşımalı öğrencilerin uzaktan eğitim ile verilen fen bilimleri dersine yönelik görüşleri. OPUS-Uluslararası Toplum Araştırmaları Dergisi, 17(Pandemi Özel Say1s1), 3893-3918. DOI: 10.26466/opus.915874 